\title{
Brachial plexus injury: An unusual devastating complication during hospitalization in intensive care unit
}

\author{
Brakiyal pleksus hasarı: Yoğun bakım ünitesinde yatış sırasında \\ olağandışı yıkıcı bir komplikasyon
}

\author{
Yusuf Erdem, MD (D), Çağrı Neyişçi, MD (D), Ahmet Burak Bilekli, MD (1) \\ Department of Orthopedics and Traumatology, Gülhane Training and Research Hospital, Ankara, Turkey
}

\begin{abstract}
Brachial plexus injury due to prolonged immobilization of the arms in a hyper-abducted position during intensive care unit (ICU) follow-up is uncommon. In this article, we present an unusual case of a 20 -year-old male drug addict who sustained unattended brachial plexus injury in left upper extremity after being bound over the axilla tightly during ICU follow-up. He had progressive numbness and near-total immobility of the left upper extremity. Atrophy, loss of muscle strength, and absence of deep tendon reflexes were observed in left upper extremity. Electrodiagnostic studies showed lower trunk partial axonal involvement. After aggressive physical therapy, patient's muscle function improved, showing full strength in all muscles innervated by median, ulnar, musculocutaneous, axillary and radial nerves. During followup of unconscious patients in ICU, clinicians and other staff should be more careful about restraining such patients by considering complications such as nerve injuries.
\end{abstract}

Keywords: Brachial plexus, drug addict; hyper-abduction, injury, intensive care unit.

Brachial plexus injuries lead to functional and physical disability with symptoms ranging from a completely paralyzed upper limb to a lack of muscle control and loss of sensation in the arm, wrist or hand. ${ }^{[1]}$ It has a predominant prevalence in adult male gender and ages between 15 and 25 years. ${ }^{[2]}$ The most common cause of brachial plexus injury in adults is traffic accident, particularly motorcycle accidents..$^{[3,4]}$
$\ddot{O Z Z}$

Yoğun bakım ünitesi (YBÜ) takibi sırasında kolların hiperabdüksiyon pozisyonunda uzun süre immobilizasyonuna bağlı brakial pleksus hasarı nadirdir. Bu yazıda, YBÜ takibinde aksillası üzerinden sıkıca bağlanmasından dolayı sol üst ekstremitesinde ihmal edilmiş brakiyal pleksus hasarı gelişen, uyuşturucu bağımlıs 20 yaşında bir erkek hastanın olağandışı bir olgusu sunuldu. Sol üst ekstremitesinde progresif hissizliği ve totale yakın immobilitesi vardı. Sol üst ekstremitede atrofi, kas kuvveti kaybı ve derin tendon reflekslerinin olmadığı gözlendi. Elektrodiagnostik çalışmalar, alt gövdede parsiyel aksonal tutulumunun olduğunu gösterdi. Agresif fizik tedavi sonrasında, hastanın kas fonksiyonu iyileşerek medyan, ulnar, muskulokütanöz, aksiller and radyal sinirlerin inerve ettiği tüm kaslarda tam güç gösterdi. Klinisyenler ve diğer personel, YBÜ'de bilinçsiz hastaların takibinde sinir hasarı gibi komplikasyonları göz önünde bulundurarak bu hastaların kısıtlanması konusunda daha dikkatli olmalıdır.

Anahtar sözcükler: Brakiyal pleksus, uyuşturucu bağımlısı, hiperabdüksiyon, hasar, yoğun bakım ünitesi.

Furthermore, traumatic or non-traumatic conditions such as crutch palsy, sports injuries, gunshot wounds, operative malpositioning, tumors, irradiation, alcoholinduced axillary trauma, traction and congenital abnormalities resulting in inflammation are reported as other common reasons causing brachial plexus injury in the literature. ${ }^{[5]}$ Prognosis is variable and associated with the site and extent of the nerve

Received: June 12, 2019 Accepted: July 03, 2019 Published online: October 24, 2019

Correspondence: Çağrı Neyişçi, MD. Gülhane Eğitim ve Araştırma Hastanesi Ortopedi ve Travmatoloji Kliniği, 06010 Etlik, Ankara, Turkey. Tel: +90 530 - 0677610 e-mail: cagri_neyis@yahoo.com 
damage. Avulsion and rupture of the nerve trunk may require nerve surgery, whereas in most cases, neuropraxia causes a temporary plexopathy which resolves spontaneously within weeks to months. In this article, we aim to present an unusual case of a unilateral brachial plexopathy caused by hyperabducted position of the arm in a drug addict patient who was admitted to intensive care unit (ICU) for a long time after loss of consciousness. ${ }^{[6]}$

\section{CASE REPORT}

A 20-year-old male patient with a history of substance abuse and related intoxication had been followed up in the ICU during one year without consciousness. The state of confusion and coma had not changed. As supposed to prolonged immobilization in deep coma, delirium symptoms were observed. He was bound to bed from his axillas and wrists tightly (Figure 1). On the $10^{\text {th }}$ day, marked edema and ecchymosis were observed in his left upper extremity. Left arm panplexopathy including progressive numbness and near-total immobility of the upper limb was diagnosed and no attempt was applied including physical therapy before he was discharged and referred to our department. He was admitted to our department on the first day after discharge from ICU. On physical examination, atrophy was observed in left upper limb, distally more pronounced. In detailed motor examination, muscle strength was recorded as $0 / 5$ elbow extension, $4 / 5$ elbow flexion, $0 / 5$ wrist and finger extension, $0 / 5$ wrist and finger flexion, $0 / 5$ fingers abduction and adduction, and $0 / 5$ thumb extension and abduction according to Oxford scale (muscle strength grading scale), respectively. ${ }^{[7]}$ There was no perspiration or temperature differences compared to the opposite

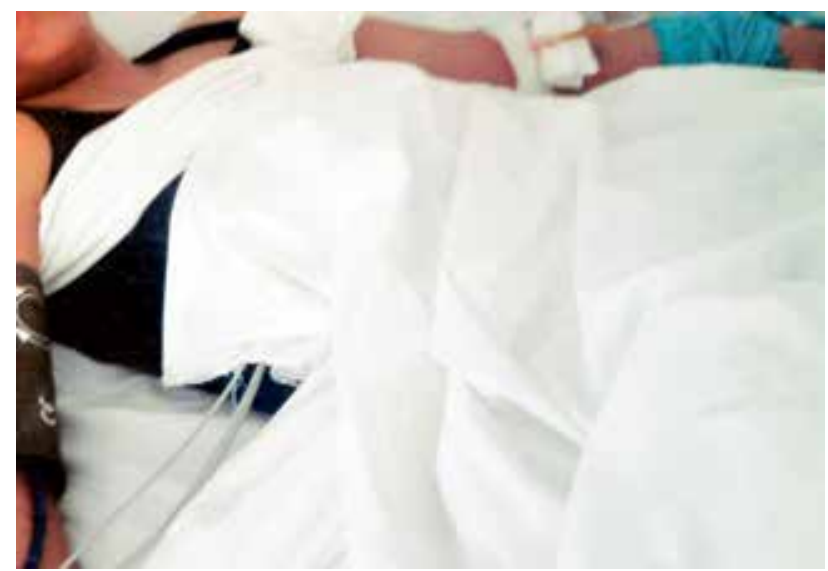

Figure 1. Patient positioning, bound tightly over arms during state of delirium. extremity; however, there was significant reduction in joint position sense and vibration. Actually, abnormal sensations were reported on lateral and dorsal aspect of forearm and both volar and dorsal aspect of wrist and hand with grade of 4 (diminished protective sensation) according to Semmes-Weinstein monofilament test. ${ }^{[8]}$ Also, deep tendon reflexes were absent and the patient's axilla showed marked hyperpigmentation and skin bruises suggestive of chronic irritation and rubbing (Figure 2). With the presence of atrophy and sensorimotor affection, brachial plexus was thought to be the probable site of the lesion. Electromyography (EMG) and nerve conduction studies (NCS), which were performed at admission, revealed an infraclavicular brachial plexus palsy with denervation of extensor of elbow, wrist, fingers, and flexors of wrist. Electrodiagnostic studies showed that multifocal motor amplitude was more affected than sensorial amplitude with slightly reduced conduction velocity, reduced compound muscle action potentials frequency, and decreased sensory nerve action potentials frequency considering subacute chronic partial axonal damage affecting posterior and medial cords more than all trunks in the left upper limb. A written informed consent was obtained from the patient.

Aggressive physical therapy including stretching and strengthening of muscles, electrical stimulation, sensorial education and range of motion exercises were started and continued for one year. The patient was followed-up during the rehabilitation period. First, his sensorial dysfunction resolved within three months and progressive improvement in motor functioning was observed during the first six months. At the end of physical therapy, triceps power was $5 / 5$, wrist and finger extension/flexion power was

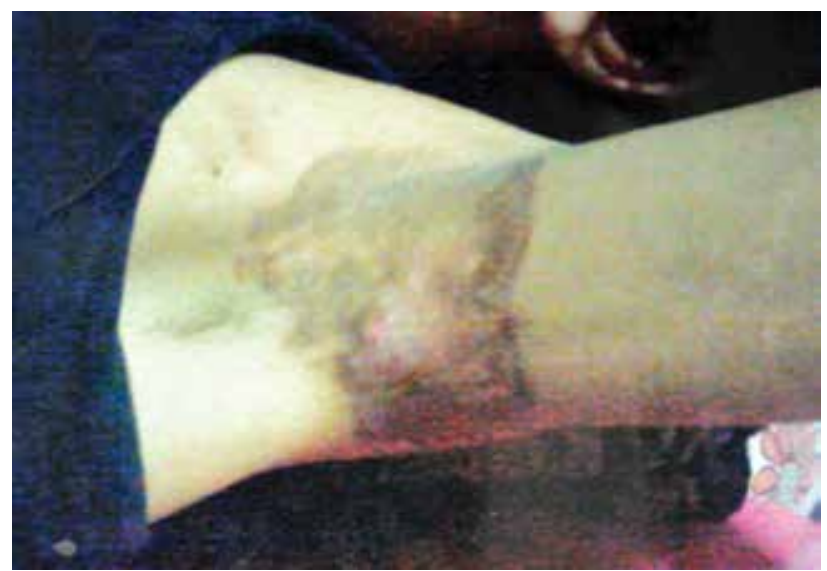

Figure 2. Hyperpigmentation and skin bruises due to chronic irritation and rubbing of bound material. 
$4 / 5$, fingers abduction and adduction power was $3 / 5$, and thumb extension and abduction power was $3 / 5$, respectively. At second year follow-up, the patient regained near-normal power of the left upper limb with complete recovery of wrist/finger extension and flexion. However, thumb and fingers adduction/ abduction powers were limited to $3 / 5$ which reduced the patient's dexterity of hand functionally.

\section{DISCUSSION}

The most common factor causing brachial plexus injuries in the young population has been described as excessive traction of the shoulder due to direct trauma. ${ }^{[9]}$ Moreover, the use of axillary crutches and shoulder braces, malpositioning during hospitalization, prone positioning during prolonged surgical procedures, tumors and inflammation were reported as causes of brachial plexus injuries due to differential pressures over nerves. ${ }^{[9-12]}$ Devitt et al. ${ }^{[13]}$ reported flaccid paralysis of upper limb with absence of deep tendon reflexes in an 18-year-old boy, while Silber et al. ${ }^{[14]}$ described a complete brachial plexus injury in a 69-year-old gentleman due to stretching following alcohol intoxication.

The mechanism of injury includes stretching, ischemia, compression or a combination of these factors. It is thought to be due to distractions of the shoulder or arm from the rest of the body. The damage increases if the arm is abducted more than $90^{\circ}$ and extended more than $30^{\circ}$ from the trunk. Meanwhile, compression over the acromion and lateral pressure on the shoulders may stretch the plexus or directly push the head of the humerus against the plexus, therefore it should be avoided. ${ }^{[15]}$ Many of the reports about the mechanism that leads to brachial plexus injuries were related to the prone positioning during surgeries, whereas to our knowledge, there is no report about the mechanism leading to brachial plexopathy in an intensive care patient due to incorrect positioning. In our case, the exact cause of the injury was postulated to be the prolonged period of immobilization with arms bound tightly in hyper-abduction position in the status of delirium which caused brachial plexus compression. Injury could have started with stretching over nerves for a long time and subsequent arm position determined the site of injury. Furthermore, prolonged immobilization in the same position may also result in focal rhabdomyolysis. This condition may compromise the blood supply to the nerves causing neural ischemia and paralysis. Focal rhabdomyolysis is a common disorder secondary to skeletal muscle trauma with prolonged immobilization due to any reason. ${ }^{[16]}$
Assessment of brachial plexus injury should include thorough neurological evaluation, supplemented by magnetic resonance imaging of the cervical spine and nerve conduction studies as needed. In doubtful cases with clinical suspicion, EMG and NCS must be performed immediately or at least three-four weeks post-injury. ${ }^{[17]}$ Wallerian degeneration and denervation changes can be seen as early as 10-15 days after injury with electrodiagnostic studies. ${ }^{[18]}$ In our case, EMG revealed abnormal findings after the patient's admission with an estimated injury time of at least 10 days, which was consistent with the literature. ${ }^{[1]}$ On the other hand, Parsonage-Turner syndrome which is characterized by the sudden appearance of shoulder pain followed by progressive motor weakness, also known as acute brachial plexus neuritis, should be considered in the differential diagnosis and ruled out by these methods mentioned above. ${ }^{[19]}$

The Seddon classification system describes three types of nerve injury including neuropraxia, axonotmesis and neurotmesis and may facilitate to classify these cases. It correlates the degree of nerve injury with the symptoms, pathology, treatment and prognosis. ${ }^{[20]}$

Initial treatment should consist of discontinuation of the compression over the injury site and include physical therapy to prevent contractures until recovery of the nerve and muscle functions. If spontaneous recovery of any nerve function is not observed clinically and/or on serial electromyogram studies, decompression surgery or tendon transfers may be considered in order to provide adaptive muscle function.

In conclusion, this case has some important messages for the readers. First, in case of necessity for prolonged immobilization in ICU, patients should not be bound tightly with arms in hyperabduction position. Moreover, the arms should be kept as close as possible to the patient's sides to avoid brachial plexus injury. We believe that ICU patients should be followed-up individually with maximum attention. Second, clinicians should suspect a possible brachial plexus injury in the event of delirium that requires strict restraint; otherwise, severe complications may develop leading to claims of malpractice and undesired medicolegal consequences.

\section{Declaration of conflicting interests}

The authors declared no conflicts of interest with respect to the authorship and/or publication of this article. 


\section{Funding}

The authors received no financial support for the research and/or authorship of this article.

\section{REFERENCES}

1. Nagano A. Treatment of brachial plexus injury. J Orthop Sci 1998;3:71-80.

2. Dubuisson AS, Kline DG. Brachial plexus injury: a survey of 100 consecutive cases from a single service. Neurosurgery 2002;51:673-82.

3. Goldie BS, Coates CJ. Brachial plexus injury: a survey of incidence and referral pattern. J Hand Surg Br 1992;17:86-8

4. Narakas AO. The treatment of brachial plexus injuries. Int Orthop 1985;9:29-36.

5. Chao S, Pacella MJ, Torg JS. The pathomechanics, pathophysiology and prevention of cervical spinal cord and brachial plexus injuries in athletics. Sports Med 2010;40:59-75.

6. Atik OS. Which articles do we prefer to publish? Eklem Hastalik Cerrahisi 2018;29:1.

7. Clarkson HM. Musculoskeletal Assessment: Joint Range of Motion and Manual Muscle Strength. Philadelphia: Lippincott Williams \& Wilkins; 2000.

8. Weinstein S. Fifty years of somatosensory research: from the Semmes-Weinstein monofilaments to the Weinstein Enhanced Sensory Test. J Hand Ther 1993;6:11-22.

9. Anwar F, McLaughlin D, Panesar BS. Bilateral brachial plexus injury. J Coll Physicians Surg Pak 2012;22:176-8.
10. Raikin S, Froimson MI. Bilateral brachial plexus compressive neuropathy (crutch palsy). J Orthop Trauma 1997;11:136-8.

11. Kent CD, Cheney FW. A case of bilateral brachial plexus palsy due to shoulder braces. J Clin Anesth 2007;19:482-4.

12. Kasahara T, Toyokura M, Furuno K, Ishida A. Bilateral brachial plexus palsies due to malpositioning after burn injury. Tokai J Exp Clin Med 2007;20;32:1-5.

13. Devitt BM, Baker JF, Ahmed M, Menzies D, Synnott KA. Saturday night palsy or Sunday morning hangover? A case report of alcohol-induced Crush Syndrome. Arch Orthop Trauma Surg 2011;131:39-43.

14. Silber E, Reilly M, Al-Moallem M, Murray NM, Khalil N, Shakir RA. Branchial plexopathy related to alcohol intoxication. J Neurol Neurosurg Psychiatry 1999;67:411-2.

15. Zhang J, Moore AE, Stringer MD. Iatrogenic upper limb nerve injuries: a systematic review. ANZ J Surg 2011;81:227-36.

16. Argov Z, Latronico N. Neuromuscular complications in intensive care patients. Handb Clin Neurol 2014;121:1673-85.

17. Gregory J, Cowey A, Jones M, Pickard S, Ford D. The anatomy, investigations and management of adult brachial plexus injuries. Orthop Trauma 2009;23:420-32.

18. Sakellariou VI, Badilas NK, Stavropoulos NA, Mazis G, Kotoulas HK, Kyriakopoulos S, et al. Treatment options for brachial plexus injuries. ISRN Orthop 2014;2014:314137.

19. Gariani K, Magistris MR, Nendaz MR. Parsonage-Turner Syndrome rather than Zoster Neuritis? Case Rep Neurol 2011;3:165-71.

20. Seddon HJ. Three types of nerve injury. Brain 1943;66:237-88. 